\title{
Liveweight changes in lambs grazing six perennial ryegrass cultivars
}

\author{
C.T. WESTWOOD and M.G. NORRISS \\ Wrightson Research, PO Box 939, Christchurch, New Zealand
}

\begin{abstract}
Liveweight changes were measured for lambs grazing six high endophyte perennial ryegrasses, in a grazing experiment run by an independent research organisation in Canterbury, New Zealand. Ryegrass cultivars were sown under code in a binary mix with white clover in February 1997. Plots were strategically irrigated to avoid moisture stress, and stocked at approximately 27 Coopworth ewe lambs per ha in May 1997. Common pasture residual mass was maintained across cultivars by strategic addition of extra lambs, with extra grazing days recorded for each replicate. Lamb liveweight gains and botanical composition of replicates were assessed quarterly.

Lamb liveweight gains differed significantly between treatments in Years 1 and 2 of this ongoing 3 year study. Lambs grazing 'Quartet' tetraploid perennial ryegrass gained, on average, $37.4 \mathrm{~kg}$ and $36.1 \mathrm{~kg}$ liveweight during Years 1 and 2 respectively, and together with 'Aries HD' (35.0 and $35.9 \mathrm{~kg}$ ) produced significantly greater liveweight gain compared with 'Grasslands Nui' (22.0 and $23.7 \mathrm{~kg}$ ) and 'Bronsyn' (22.5 and $24.1 \mathrm{~kg}$ ), $\mathrm{LSD}_{0.05}$ $=6.0$ and 7.4. Lambs grazing 'Embassy' gained $31.6 \mathrm{~kg}$ and $28.7 \mathrm{~kg}$, and 'Vedette' $29.8 \mathrm{~kg}$ and $28.0 \mathrm{~kg}$. Extra grazing days expressed as a percentage of base grazing days were between 3.8 and $6.7 \%$ across cultivars for Year 1 and between 2.0 and $6.5 \%$ across cultivars for Year 2. This study demonstrated significant differences in animal productivity between perennial ryegrass cultivars that produce comparable yields of dry matter. Differences may reflect variation in forage quality, endophyte toxins, clover content in the sward or other unidentified cultivar characteristics.
\end{abstract}

Keywords: digestibility, endophyte, lamb, liveweight, perennial ryegrass, tetraploid

\section{Introduction}

Animal production from pastures is determined primarily by the amount of herbage on offer (Poppi et al. 1987), however forage quality (Holmes \& Wilson 1984) and toxins associated with endophyte - ryegrass interactions (Bluett et al. 1997; Fletcher 1993; Fletcher 1998) can modify the performance of grazing animals. Enhanced understanding of the nutritional requirements of ruminants has enabled plant breeders to refocus breeding objectives, with selection for improved forage quality and changed profiles of endophyte alkaloids. Preliminary assessments of new ryegrass cultivars developed for improved nutritive value, demonstrate significant potential for improved animal production (Bluett et al. 1997; Bluett 1999; Westwood \& Norriss, unpublished data). Substantive investigation of interactions between animal performance and pasture quality factors, including digestibility and tetraploidy, is lacking under New Zealand pastoral conditions. The objective of this study was to compare liveweight gains by lambs grazing five new high endophyte perennial ryegrass cultivars, using Grasslands Nui as a control. This paper summarises results from Years 1 and 2 of a 3-year ongoing study.

\section{Materials and methods}

\section{Pasture establishment and management}

Three replicates of six commercially available perennial ryegrass cultivars were sown in Canterbury, New Zealand during February 1997. Replicates 1 and 2 were located at Lincoln; the third replicate was at Winchmore, approximately $70 \mathrm{~km}$ southwest of Lincoln. Plot sizes were 0.425 ha, 0.325 ha and 0.450 ha for replicates 1,2 and 3, respectively. Treatments were diploid Lolium perenne cultivars 'Nui' (control), 'Aries HD', 'Bronsyn', 'Embassy' and 'Vedette', and the tetraploid ryegrass cultivar 'Quartet'. Seed of test cultivars was verified with $>90 \%$ endophyte infection before sowing, however the level of 'Nui' was not determined. Level of endophyte infection was verified for all cultivars by microscopic examination of tillers in autumn 1999. Level of infection was greater than $91 \%$ for test cultivars while 'Nui' was $48 \%$ infected. Sowing rates were $25 \mathrm{~kg}$ / ha (tetraploid), and $18 \mathrm{~kg} / \mathrm{ha}$ (diploid). Trifolium repens cv 'Grasslands Challenge' was sown with all cultivars at $3 \mathrm{~kg} / \mathrm{ha}$. Clover content was assessed quarterly by herbage dissection. Irrigation was by overhead sprinklers for replicates 1 and 2, while replicate 3 received water by border dike (flood) irrigation. Target available soil moisture levels were $>40 \%$ of field capacity. 
Superphosphate was applied annually to maintain an Olsen $\mathrm{P}$ of $20 \mathrm{ppm}$, and $\mathrm{S}$ of $8 \mathrm{ppm}$; $\mathrm{pH}$ was approximately 5.8 .

\section{Study animals}

Cultivars were stocked at a rate of approximately 27 Coopworth ewe lambs/ha. Animals were randomly allocated to cultivars in May 1997, then re-randomised and reallocated to cultivars at the beginning of each subsequent quarterly grazing period. New lambs were allocated to the trial in February 1998, remaining on trial until removal in February 1999 at which time new animals were introduced. Lambs were weighed on to each cultivar at the beginning of each grazing period and weighed monthly thereafter, with net weight gain per lamb calculated for each grazing period. Lambs were assessed for ryegrass staggers during the third week of March in both years, using subjective assessment based on severity of clinical signs on a scale of $0-5$, where 0 is no symptoms and 5 is severe muscle tremors and collapse (Keogh 1973).

\section{Grazing management}

Grazing periods were as follows: Year 1: winter: 15/5/ 97-22/8/97; spring: 23/8/97-31/10/97; summer: $1 / 11 /$ 97-3/2/98; and autumn: 4/2/98-6/5/98; Year 2: winter: 26/5/98-18/8/98; spring: 20/8/98-30/10/98; summer: 7/11/98-4/2/99; and autumn 19/2/99-26/4/99. The autumn grazing period was shortened during Year 2 due to severe ryegrass staggers across both Lincoln replicates.

For each replicate in each grazing period, stockingrate for all cultivars was determined by the cultivar with the lowest pasture mass. Pasture mass was visually assessed by the same operator for the duration of the study. Cultivars were managed to a common pasture mass by addition of extra lambs following monthly assessment of pasture mass. Extra grazing days were recorded, however additional lambs were not weighed. Animals were set stocked in spring, with a 3 -paddock rotation in summer and autumn, and a 2-day shift in winter. The trial was independently managed, with test cultivars coded to avoid bias.

\section{Results and discussion}

Lamb liveweight gain was influenced significantly by the perennial ryegrass cultivar during the first 2 years of this 3-year study (Figures 1 and 2). Significantly more liveweight was gained by lambs grazing 'Quartet' compared with lambs grazing 'Nui', 'Vedette' or 'Bronsyn' during Year 1 and Year 2 of the study. Liveweight gain for lambs grazing 'Aries HD' was significantly greater than those grazing 'Nui' and
'Bronsyn' during both years of the study. Significantly different liveweights from lambs grazing different perennial ryegrass cultivars that produce comparable yields of dry matter have been reported previously (Fletcher et al. 1991; Bluett et al. 1997). The small and inconsistent differences in extra grazing days between treatments suggests that each cultivar was managed to near potential for pasture production (Table 1).

Figure 1 Mean liveweight gain per lamb $(\mathrm{kg})$ during Year 1. $\operatorname{LSD}_{(0.05)}=3.5$ (winter); 2.4 (spring); 2.7 (summer); 3.1 (autumn).

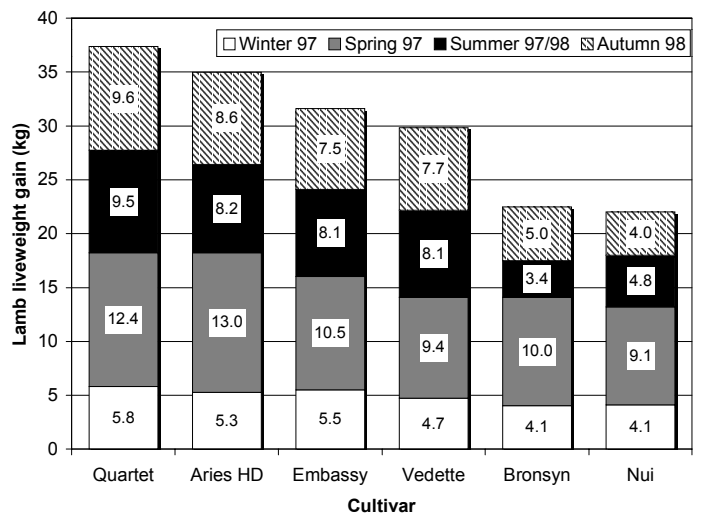

Figure 2 Mean liveweight gain per lamb (kg) during Year 2. $\operatorname{LSD}_{(0.05)}=3.3$ (winter); 5.8 (spring); 3.0 (summer); 3.2 (autumn).

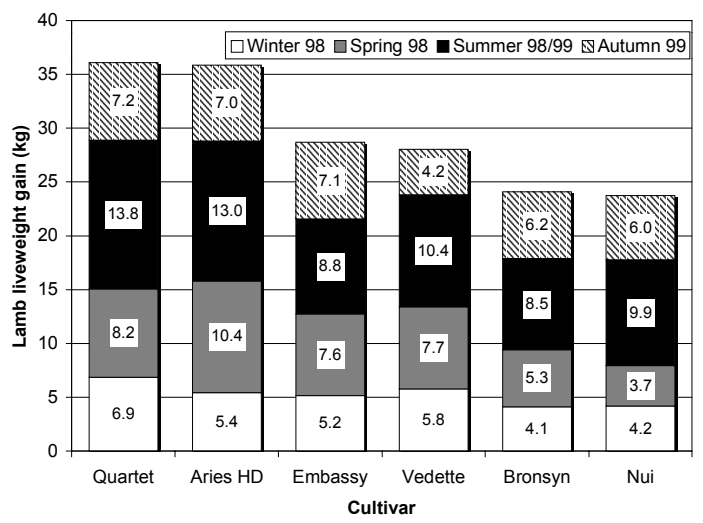

Reasons for significantly different performance by lambs in this study could be due to a number of factors. Improved digestibility and/or tetraploid characteristics associated with 'Aries HD' and 'Quartet' cultivars, respectively, may partly explain greater liveweight gains by lambs grazing these cultivars. Selection for reduced aftermath heading has increased organic matter digestibility of dry matter (DOMD) values for 'Aries 
Table 1 Percent extra grazing days during Years 1 and 2, expressed as [(extra grazing days)/(total base grazing days)] $\times 100$.

\begin{tabular}{|c|c|c|c|c|c|c|c|c|c|c|}
\hline \multirow[b]{2}{*}{ Cultivar } & \multicolumn{2}{|c|}{------ Winter ------ } & \multicolumn{2}{|c|}{------ Spring ------ } & \multicolumn{2}{|c|}{------ Summer ------ } & \multicolumn{2}{|c|}{------ Autumn ------ } & \multicolumn{2}{|c|}{------ Mean ------ } \\
\hline & Year 1 & Year 2 & Year 1 & Year 2 & Year 1 & Year 2 & Year 1 & Year 2 & Year 1 & Year 2 \\
\hline Aries HD & 6.4 & 0 & 5.2 & 3.0 & 3.9 & 3.7 & 0 & 6.8 & 5.2 & 4.5 \\
\hline Bronsyn & 3.6 & 0 & 0.9 & 3.8 & 18.0 & 7.0 & 0 & 12.8 & 7.5 & 7.9 \\
\hline Embassy & 10.0 & 0 & 5.2 & 5.6 & 5.3 & 8.3 & 0 & 12.3 & 6.8 & 8.7 \\
\hline Nui & 2.8 & 0 & 2.2 & 4.6 & 7.8 & 2.5 & 0 & 1.1 & 4.3 & 2.7 \\
\hline Quartet & 10.0 & 0 & 6.8 & 2.7 & 0.7 & 2.5 & 0 & 12.6 & 5.8 & 6.7 \\
\hline Vedette & 13.6 & 0 & 2.5 & 5.6 & 11.7 & 10.1 & 0 & 5.1 & 9.3 & 6.9 \\
\hline
\end{tabular}

Table 2 Clinical ryegrass staggers (0-5 scale, Keogh, 1973; mean of three replicates) reported for cultivars during autumn of Year 1 and autumn of Year 2.

\begin{tabular}{|c|c|c|c|c|c|c|c|c|}
\hline \multirow[b]{2}{*}{ Cultivar } & \multicolumn{2}{|c|}{---- Lincoln rep 1 ---- } & \multicolumn{2}{|c|}{$\begin{array}{l}\text { - Replicate } \\
- \text {--- Lincoln rep } 2\end{array}$} & \multicolumn{2}{|c|}{---- Winchmore ----- } & \multicolumn{2}{|c|}{-------- Mean -------- } \\
\hline & Year 1 & Year 2 & Year 1 & Year 2 & Year 1 & Year 2 & Year 1 & Year 2 \\
\hline Aries HD & 1.2 & 1.2 & 1.3 & 2.6 & 0.5 & 0 & 1.0 & 1.3 \\
\hline Bronsyn & 3.5 & 1.4 & 1.9 & 3.7 & 0.6 & 0 & 2.0 & 1.7 \\
\hline Embassy & 1.6 & 3.3 & 1.8 & 2.9 & 0.5 & 0 & 1.3 & 2.1 \\
\hline Nui & 0 & 0 & 0 & 0 & 0 & 0 & 0 & 0 \\
\hline Quartet & 3.8 & 2.8 & 2.8 & 3.3 & 0.9 & 0 & 2.5 & 2.0 \\
\hline Vedette & 1.5 & 2.7 & 2.7 & 1.8 & 0.6 & 0 & 1.6 & 1.5 \\
\hline
\end{tabular}

HD' during the summer months by between 1.6 and $3.1 \%$ relative to 'Nui' (Norriss, unpublished data). Higher lamb liveweights associated with the tetraploid ryegrass 'Quartet' may reflect increased intake of dry matter (van Wijk 1988) and enhanced nutritive value (Castle \& Watson 1971) including increased concentrations of water soluble carbohydrates (van Wijk 1988) associated with tetraploid grasses. Improved animal performance associated with tetraploidy has been reported previously (van Wijk 1988; Vipond et al. 1993).

It is unlikely that benefits associated with tetraploidy and/or improved digestibility can explain entirely the significantly different lamb performance in the current study. Negative associations between endophyte alkaloids and animal performance have been reported previously (Fletcher 1998) therefore the role of endophyte as a modifier of lamb performance in this study must be considered. Severity of ryegrass staggers, a neurological condition associated with lolitrem B (Fletcher 1998), differed between cultivars (Table 2). Lambs grazing 'Quartet' and 'Bronsyn' were more severely affected by staggers. In comparison, no clinical staggers were observed for lambs grazing 'Nui', while lambs grazing 'Aries HD', 'Embassy' and 'Vedette' showed intermediate levels of staggers. Despite these observed differences, we found no evidence for a negative association between severity of ryegrass staggers and animal performance. Incidence of staggers was greater for lambs grazing 'Quartet', however 'Quartet' supported the highest mean lamb liveweight gain. These findings suggest that lolitrem B may be less responsible for reduced animal performance relative to other endophyte associated alkaloids. More work is required to elucidate the relationship between lolitrem $\mathrm{B}$, ryegrass staggers and animal performance.

Testing of individual tillers for endophyte presence in autumn of Year 2 showed $48 \%$ infection for 'Nui', compared with between $91 \%$ and $100 \%$ for test cultivars. While $48 \%$ endophyte infection did not induce clinical ryegrass staggers, lack of staggers does not preclude negative effects associated with other endophyte alkaloids. In a comparison of liveweight gains from lambs grazing 'Aries HD' or 'Yatsyn 1' high endophyte perennial ryegrass, Bluett et al. (1997) reported $61 \%$ greater weight gains $(\mathrm{P}=0.035)$ for lambs grazing 'Aries HD' during summer months. The authors concluded that an association between an endophyte alkaloid, ergovaline, and animal performance may exist because while nutritive value, concentrations of lolitrem B and dry matter yield did not differ significantly between cultivars, significantly $(\mathrm{P}=0.026)$ higher concentrations of ergovaline were reported for 'Yatsyn 1' (0.42 ppm) compared with 'Aries HD' (0.23 ppm) (Bluett et al. 1997). Negative associations between high concentrations of ergovaline and lamb performance have been reported previously (Fletcher 1993; Fletcher et al. 1997). Concentrations of endophyte alkaloids were not quantified in the current experiment therefore we cannot speculate on the role of endophyte alkaloids as contributors to the significantly different animal performance found across cultivars. Limited evidence exists for reduced concentrations of ergovaline associated with 'Aries HD' and 'Quartet' (0.18 ppm) 
Table 3 Botanical composition (legume content expressed as \% of total sward, mean of three replicates) for cultivars during each season for Year 1 and Year 2.

\begin{tabular}{|c|c|c|c|c|c|c|c|c|}
\hline \multirow[b]{2}{*}{ Cultivar } & \multicolumn{2}{|c|}{------- Winter ------- } & \multicolumn{2}{|c|}{------- Spring ------- } & \multicolumn{2}{|c|}{------ Summer ------ } & \multicolumn{2}{|c|}{------- Autumn ------- } \\
\hline & Year 1 & Year 2 & Year 1 & Year 2 & Year 1 & Year 2 & Year 1 & Year 2 \\
\hline Aries HD & 0 & 0 & 5 & 12 & 8 & 16 & 6 & 20 \\
\hline Bronsyn & 0 & 0 & 4 & 12 & 6 & 8 & 3 & 14 \\
\hline Embassy & 0 & 0 & 5 & 10 & 6 & 14 & 5 & 13 \\
\hline Nui & 0 & 0 & 5 & 9 & 7 & 6 & 5 & 12 \\
\hline Quartet & 0 & 0 & 3 & 11 & 6 & 20 & 5 & 15 \\
\hline Vedette & 0 & 0 & 4 & 11 & 7 & 11 & 5 & 14 \\
\hline LSD $_{0.05}$ & - & - & 2.9 & 5.5 & 2.7 & 5.9 & 2.6 & 5.8 \\
\hline
\end{tabular}

compared with 'Yatsyn 1' $(0.78 \mathrm{ppm})$ (Norriss, unpublished data), indicating that further investigation of the relationship between endophyte alkaloids and lamb performance is warranted.

White clover content of mixed swards can significantly and positively influence performance of grazing animals (Poppi et al. 1987). During Year 1, clover content as a percentage of total sward, was low ranging from $0 \%$ (winter) to $8 \%$ (summer; Table 3). Limited presence of clover in the sward and small differences between cultivars suggest that during Year 1, sward clover content was unlikely to have contributed to marked differences in animal performance. In comparison, in the second year, average clover content during the summer ranged from 6\% ('Nui') to 20\% ('Quartet') of the total sward. Differences in clover content probably contributed to different lamb liveweight gains observed during Year 2. The low clover content of the 'Nui' sward was unexpected because a relatively low endophyte infection should favour clover establishment and growth. The high clover content of the 'Quartet'based swards is a favourable feature and probably reflects tiller characteristics associated with tetraploidy, with larger but fewer tillers creating more space for clover stolons. It is possible also that clover may be less severely selected in tetraploid swards because of enhanced palatability of tetraploids relative to diploid cultivars.

\section{Conclusions}

Liveweight gains by lambs grazing six perennial ryegrass cultivars differed significantly during the first 2 years of a 3-year ongoing study. Tetraploidy and selection for improved digestibility may partly explain improved animal performance on particular cultivars. Small but consistent improvements in digestibility have been demonstrated for both 'Aries HD' and 'Quartet' under rotational grazing systems. Significantly different liveweight gains may also result from different endophyte alkaloid profiles and (in Year 2) dissimilar clover contents. The study highlights limitations associated with the use of forage dry matter production as the sole predictor of animal performance. Future evaluation of new grass cultivars must incorporate animal performance as well as dry matter production, to permit more accurate evaluation of potential animal benefits associated with new cultivars.

\section{ACKNOWLEDGEMENTS}

Wrightson Research thank the Sheep Forage Systems Group of AgResearch, Canterbury for undertaking the research described in this paper.

\section{REFERENCES}

Bluett, S.J.; Hodgson, J.; Kemp, P.D.; Barry, T.N. 1997. Animal evaluation of Aries HD perennial ryegrass selected for high digestibility. Proceedings of the New Zealand Grassland Association 59: 245-249.

Bluett, S.J. 1999. An evaluation of the nutritive value and endophyte status of a new perennial ryegrass (Lolium perenne) cultivar (Aries HD). PhD thesis, Massey University.

Castle, M.E.; Watson, J.N. 1971. A comparison between a diploid and a tetraploid ryegrass for milk production. Journal of agricultural science, Cambridge 77: 69-76.

Fletcher, L.R. 1993. Heat stress in lambs grazing ryegrass with different endophytes. Proceedings of the International Symposium on Acremonium/Grass Interactions 2: 114-118.

Fletcher, L.R.; Popay, A.J.; Tapper, B.A. 1991. Evaluation of several lolitrem-free endophyte/ perennial ryegrass combinations. Proceedings of the New Zealand Grassland Association 53: 215-219.

Fletcher, L.R.; Sutherland, B.L.; Fletcher, C.G. 1997. Effect of ambient temperature and black-globe temperature on plasma prolactin levels in ewes grazing endophyte-free and endophyte infected ryegrass. pp. 425-427. In: Neotyphodium/Grass Interactions. Eds. Bacon, C.W.; Hill, N.S. New York, Plenum Press. 
Fletcher, L.R. 1998. Endophyte on the dairy farm, is it a problem? Dairy cattle and industry; Proceedings of the New Zealand Veterinary Association Conference: $119-132$.

Holmes, C.W.; Wilson, G.F. 1984. Nutrition: Food intake and nutritive value. pp. 131-150. In: Milk production from pasture. Butterworths of NZ (Ltd), Wellington, New Zealand.

Keogh, R.G. 1973. Induction and prevention of ryegrass staggers in grazing sheep. New Zealand journal of experimental agriculture 1: 55-57.

Poppi, D.P.; Hughes, T.P.; L'Huillier, P.J. 1987. Intake of pasture by grazing ruminants. pp. 55-63. In: Livestock feeding on pasture, Occasional Publication
No. 10, New Zealand Society of Animal Production. Ed. Nichol, A.M. THL Publishers, Singapore. van Wijk, A.J.P. 1988. Breeding tetraploid perennial ryegrass for forage. pp. 35-41. In: Proceedings of the Annual Grass Breeders Work Planning Conference. Eds. Barker, R.E.; Meyer, W.W. Oregon State University Publishers.

Vipond, J.E.; Swift, G.; McClelland, T.H.; Fitzsimons, J.; Milne, J.A.; Hunter, E.A. 1993. A comparison of diploid and tetraploid perennial ryegrass and tetraploid ryegrass-white clover swards under continuous sheep stocking at controlled sward heights. 2. Animal production. Grass and forage science 48: 290-300. 
